\title{
Customers' Evaluation of Service Quality in the Ghanian Banking Industry: A Case Study of Cal Bank Limited
}

\author{
Bismark Addai \\ School of Finance, Zhongnan University of Economics and Law, Wuhan, China \\ E-mail: abismarks@hotmail.com \\ Annette Serwaa Agyeman \\ Credit Department, Juaben Rural Bank, Ghana \\ Adjei Gyamfi Gyimah \\ Department of Finance, Career Spring Institute, Ghana
}

Received: Jan. 5, 2019 Accepted: Feb. 13, 2019 Published: Mar. 19, 2019

doi:10.5296/ifb.v6i1.14177ＵRL: http://dx.doi.org/10.5296/ifb.v6i1.14177

\begin{abstract}
Financial services are intangible and the only way to attract and retain customers is to seek out what they expect and design services to meet these expectations. This study was conducted to investigate customers' evaluation of service quality in the Ghanaian banking industry using Cal Bank Limited as a case study institution and to recommend effective ways to improve the quality of service delivery. A convenience sampling technique was utilized in a 200 sample-size selection from Cal Bank customers in the Kumasi Metropolis, Ghana. Structured questionnaire adopted from the SERVQUAL instrument was used to gather primary data from customers and SPSS Statistics version 21 was employed as the main statistical tool. It is evident in this study that customers are dissatisfied with the overall level of service quality provided by the bank. However, customers are satisfied with empathy and assurance dimensions. The study further revealed that all the five dimensions of service quality significantly influence the service quality of the bank and the dimension with greatest impact is reliability, which has the highest coefficient. This means that the bank needs to pay much attention to reliability as a service quality component and improve upon the reliable services provided to customers whilst maintaining or improving the other dimensions.
\end{abstract}

Keywords: Service Quality, Customer, Evaluation, Expectation, Perception, Gap model, Bank 


\section{Introduction}

In ancient times, customers were perceived ignorant of what they wanted and therefore accepted what was available. Quality was defined from the producers' or service providers' perspective with little or no consideration of the customer perceptions and expectations. In those days, producing high quality product or service in the eyes of the producer or service provider, guaranteed business success. Most banks competed in terms of financial prowess rather than service quality. People, time, and systems were devoted to managing assets and cash rather than managing customers and services. Most bank systems were designed to control customers rather than satisfy customers. Products and procedures were set up for the convenience of the bank rather than that of the customer (Domingo, 2003).

Currently, the customer assumes a focal point of all business decisions right from the conception of a product or service to delivery. Apparently, the success of modern business hinges on how customers are served and how the customers evaluate and perceive such products or services. The nature of the service may not matter but the value customers place on such service is of significant importance in attracting and retaining customers. The intensity of competition in the Ghanaian banking industry calls for improvement in quality to meet customer expectation rather than simply competing for financial prowess if banks are to survive. In the midst of such intense competition, the issue of service quality is paramount to the banking firms in terms of their survival, profitability and growth. Banks operate in an open system where customer plays an active role as a co-producer in the production and delivery of the service; this is unlike the manufacturing of products in which the entire production process is alienated from the customer Fitzsimmons and Fitzsimmons (2011). For service, the assessment of quality is made during the service delivery process since production and consumption of the service happen at the same time.

Perceived service quality is the driving force for competition in the Ghanaian banking industry (Nukpezah \& Nyumoyo, 2009). Apparently, banks are competing based on perceived service quality which is the perception of customers regarding service quality of the banks. Service quality has various dimensions and each customer places different level of importance on each dimension of service quality. Each bank has identified themselves with at least one of the dimensions of service quality that they think it will drive customers perceived service quality satisfaction, loyalty, and retention. The service providers' perception of service quality may be quite different from what customers perceive as service quality. If the banks are to compete in providing quality service to customers, it is important to understand the customer perception and expectation of quality service. The aim of this research is therefore to reveal the dimension of service quality that greatly drives customers perceived service quality at Cal Bank Limited.

There is considerable amount of research on the quality of service of firms in the banking Industry in Ghana which includes the works of researchers such as Hinson et al. (2006); Nukpezah and Nyumoyo (2009); Bonsu and Mensah (2013); Amoako 2012. However, these studies are only comparative studies of the quality of service of two or three firms in the banking industry. One notable research among them is the one conducted by Hinson, 
Mohammed and Mensah (2006). They compared the service quality of three banks and found that customers' expectation on all the dimensions of service quality were not met in any of banks studied. Nevertheless, Hinson, Mohammed and Mensah (2006) did not consider which dimension drives overall service quality in those banks but only compared service quality among banks. Such studies may not give a thorough and in-depth understanding of the dimension of service quality that drives customers' perception of service quality in the banking industry.

Therefore, the empirical issue and a thorough understanding of customer perception of service quality in the banking industry of Ghana still remain unresolved. There is therefore the need to know the dimension that greatly influences the overall service quality in the Ghanaian banking industry using Cal Bank as the case study. Better understanding of the dimensions which greatly influence service quality that customers depend on to judge the quality of services provided will be a sound basis for continuous improvement in the quality of service offered to customers so as to satisfy and retain them.

This study would provide a framework for Cal Bank, banks and other financial institutions in Ghana to improve their services by providing strategies and ensuring total service quality in the design and delivery of their services. It will also help banks to know which dimension significantly influences customers' evaluation of the overall service quality so as to build on that to satisfy their customers. The subsequent sections present: research objectives; review of relevant literature including the gap model, prior empirical studies, the research framework; the research methodology, data analyses and the conclusion of the entire study.

\subsection{Research Objectives}

The main objective of this study is to assess the dimensions customers use to judge service quality and discover the dimension that greatly influences overall service quality in the Ghanaian banking industry using Cal Bank Ghana Limited as a case study institution. The following specific objectives will therefore be achieved in order to accomplish the main objectives of the study.

(1) To examine the different customer segments of the bank.

(2) To analyze the service quality as determined by the five dimensions of service quality and the 'GAP Model'.

(3) To identify the key dimension which has greater influence on overall service quality

\section{Literature Review}

This section reviews prior studies on service quality related to this study: dimensions of service quality, customer expectations and perceptions, the GAP model, and prior empirical evidence on the quality of banking services.

\subsection{Dimensions of Service Quality}

One of the earliest authors, Gronroos (1984) conceptualized service quality as a bi-dimensional construct. According to him, customers' perceptions of service process are 
divided into two dimensions. Gronroos designated these dimensions as: Functional and Technical. Functional quality refers to the quality of the service process while technical quality refers to the outcome of the service process. Parasuraman et al. (1985) also conceptualized service quality as a ten dimensional construct. These ten dimensions were identified as credibility, security, accessibility, communication, understanding the consumer, tangibles, reliability, responsiveness, competence, and courtesy. Thus customers' perception of service quality is a function of the evaluation of all the ten components. Parasuraman et al. (1988) consolidated the ten dimensions into five dimensions. They identified five principal dimensions that customers use to judge service quality: reliability, responsiveness, assurance, empathy and tangibles. Zeithaml and Bitner (1996) observed that all the five dimension of Parasuraman et al. are relevant to all service firms but more particularly to the banking sector.

Reliability is the ability to perform the promised service both dependably and accurately (James and Mona Fitzsimmons, 2011). Reliability is one of the most important factors towards banking service because the customer would like to ensure that service provider is able to perform the promised service adequately and accurately (Zeithaml et al., 2009). Reliability pertains to good reputation of the bank; Safety and Assurance are relevant for customers' trust and the use of ATM (Automatic Teller Machine) and credit card; Communication ensures that customer complaints and banks efforts to address them is exchanged between management and customer.

Responsiveness is the willingness to help customers and to provide prompt service (Williams et al., 1999). Keeping customers waiting, particularly for no apparent reason, creates unnecessary negative perception of quality. If a service failure occurs, the ability to recover quickly and with professionalism can create very positive perception of quality. Thus, it is important to make sure the employees of the bank are in good manners and willing to help customer since perceived employee serviceability positively affect customers' perception of total service quality in the bank (Hartline \& Jones 1996; Williams et al., 1999).

Assurance is knowledge and courtesy of employees as well as their ability to convey trust and confidence. The assurance dimension includes the following features: competence to perform the service, politeness and respect for the customer, effective communication with the customer, and the general attitude that the server has the customer's best interest at heart (James and Mona Fitzsimmons 2011). In the banking industry, most customers will expect to feel safe and secure in doing their transaction with the employees or receptionist of the bank.

Empathy is the provision of caring, individualized attention to customers. Empathy includes the following features; approachability, sensitivity and effort to understand the customer's needs. This dimension was used to measure the service quality based on the ability of the management of banks to understand the customer needs and requirements. Levesque and McDougall, (1996), also stated that Empathy is crucial in facilitating customers' access and dealing with the bank.

Tangibles refer to the appearance of physical facilities, equipment, personnel and communication materials. The condition of the physical surrounding e.g. cleanliness is a tangible evidence of the care and attention that are exhibited by the service provider. Jamal 
and Naser (2002) indicated that tangibility is also a relevant dimension of service quality of banks. They noted that customers evaluate service quality of banks based on tangibles such as the building and the physical layout that constitute the service environment.

\subsection{Customer Expectations, Perceptions and Service Quality}

According to Fitzsimmons and Fitzsimmons (2011), customers generally enter a service situation with some expectations. These expectations are formed by either word of mouth, previous experience of the same or similar service or simply expectations generated by the customer. Again by the same authors, a customer usually undertakes a service experience with some perceived expectation and thereafter develops a perception of that experience.

Customer expectation is understood as "desires or wants of consumers" or "what they feel the service provider should offer rather than would offer" (Zeithaml et al., 2009). Expectations are created by several factors. Sometimes unrealistically high expectations occur especially, when customers perceive the business support services to solve their problems. This may be as a result of unrealistic marketing activities and strategies that instead of concentrating on the core service quality, emphasis is placed on social relationships, so uncertainties emerge leading to mistrust (Lovelock \& Wirtz 2007). Albrecht (2003) defined perception as the act of discerning, realizing, and becoming aware of something through the senses. To him, the key point in assessing customer perception is useless unless the information leads to actionable feedback.

Fitzsimmons and Fitzsimmons (2011) in their book, "Service operations management" with reference to the work of Parasuraman et al. (1985) identified three possible outcomes from the relationship between the two concepts-perception and expectation. They say when perceptions do not meet expectations, service quality is deemed unacceptable; where expectations are confirmed by perceived service, quality is satisfactory; and when perception of the service exceeds expectations, it is called exceptional quality, satisfaction is said to be enhanced.

Attitude towards the excellence of service quality and customers expected and perceived service quality is the difference between the arithmetic sum of customers' perceptions and expectations of those five dimensions of service quality. A better understanding and proper management of customers' expectations through accommodating expectations; thus not saying customers are too demanding or shaping expectations i.e. communicating well to make customers expect just what you can provide builds lasting customer loyalty and retention. Perceived service quality and customer satisfaction will result from how close the actual service performance, the service process and outcome matches the customers' expectations (Ojasalo, 2001).

\subsection{The Gap Model}

The most well-known model of service quality is the model of Parasuraman et al. (1985) which is widely utilized in literature. The authors proposed that service quality is a function of the differences between expectation and performance along the quality dimensions. They developed a service quality model based on gap analysis. The model attempts to show the 
salient activities of the service organization that influence the perception of quality. Moreover, the model shows the interaction between these activities and identifies the linkages between the key activities of the service organization which are pertinent to the delivery of a satisfactory level of service quality. The links are described as gaps or discrepancies: that is to say, a gap represents a significant hurdle to achieving a satisfactory level of service quality (Ghobadian et al., 1994).

The model exhibits how service emerges. The upper portion of the model includes phenomena related to customers, while the lower part includes phenomena related to the service provider. The expected service is a function of the customer's past experience and personal needs and of word of mouth communication. It is also influenced by the market communication activities. The service experienced, which in this model is termed as perceived service, is the outcome of a series of internal decisions and activities. Management perceptions of customer expectations guide decisions regarding service quality specifications to be followed by the company when service delivery (i.e. the execution of the service express) occurs. The customer experiences the service delivery and production process as a process-related quality component and the technical solution received by the process as an outcome-related quality component.

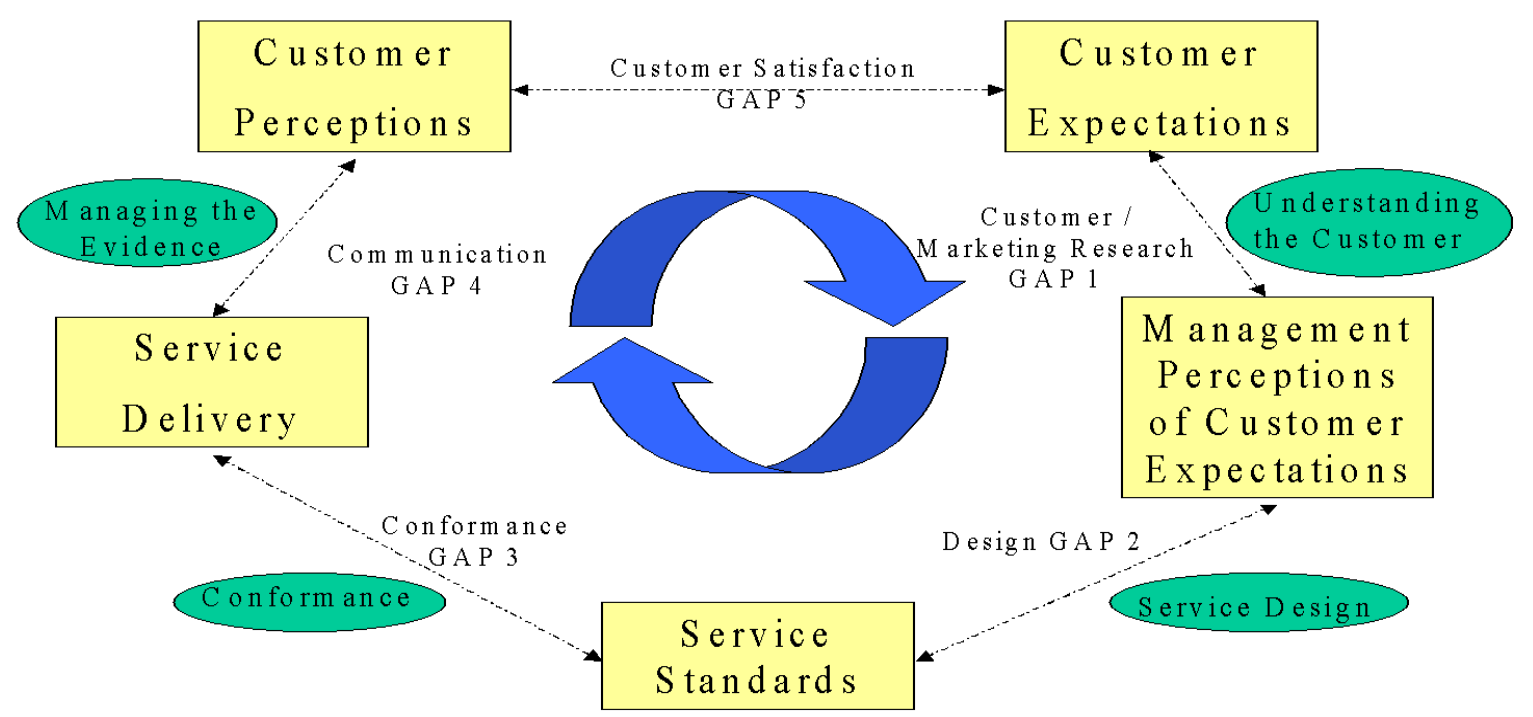

Figure 1. The gap model

Source: Fitzsimmons and Fitzsimmons, 2011.

As illustrated in figure 1, marketing communication can influence the perceived service and also the expected service. This basic model demonstrates the steps that have to be considered in analyzing and planning service quality. The five discrepancies (also called service gaps) 
between the various elements of the structure are a result of inconsistencies in the quality management process. The five gaps in figure 1 are discussed below:

GAP 1 occurs when management perceives the quality expectations inaccurately due to inaccurate information from market research and demand analyses. GAP 2 signifies service quality specifications are not consistent with management perceptions of quality expectations due to planning errors or insufficient planning procedures. GAP 3 means that quality specifications are not met by performance in the service production and delivery process. GAP 4 occurs when promises given by market communication activities are not consistent with the service delivered. GAP 5 differently referred to as the ultimate gap signifies that the perceived or experienced service is not consistent with the expected service.

Parasuaraman et al. (1985) further explain that service quality should be measured by subtracting customers' perception scores from customer expectation scores $(\mathrm{Q}=\mathrm{P}-\mathrm{E})$. The greater the positive score represents the greater the positive amount of service quality and vice-versa.

This study employs the SERVQUAL instrument in assessing the ultimate Gap (GAP 5) to determine the discrepancies between customers' expectations and perceptions on the five dimensions of service quality in order to identify the dimension for which such discrepancy significantly affect overall service quality in Cal Bank Ghana Ltd.

\subsection{Empirical Review of Service Quality Dimensions in the Banking Industry}

Rahaman et al. (2011) explored service quality of the private commercial banks in Bangladesh, the findings from their study revealed that, one of the primary causes of service quality design failure is the lack of understanding of the evolving need and preferences of targeted customers. Again, Kheng et al. (2010) employed the SERVQUAL model developed by Parasuraman with five dimensions to evaluate the impact of service quality on customer loyalty among bank customers in Penang, Malaysia. Customer satisfaction was used as an intermediate variable. The findings show that improvement in service quality can enhance customer loyalty. The service quality dimensions that play a significant role in the equation are reliability, empathy, and assurance. Saghier and Demyana (2013), in their research on service quality dimensions and customers' satisfactions of banks in Egypt also revealed that customer satisfaction in the Egyptian banking services is significantly affected by Reliability, Empathy, Assurance and Responsiveness, while the effect of the dimension of Tangibility does not have any significant impact on customer satisfaction.

Nukpezah and Nyumoyo (2009), in their research on service quality of banks in Ghana, discovered that there is a direct link between service quality variables and customer satisfaction in the banking industry. Customer satisfaction helps in customer loyalty and retention and that the cost of attracting new customers far exceeds the cost involved in retaining existing ones. They also found that empathy, reliability, image, and reputations are important indicators of customers' satisfaction in the banking sector of Ghana. However, they found that competitive pricing had no influence on service quality perceived by customers of the Ghanaian banking industry. 
In an investigation of service quality perception of three banks in Ghana: Barclays bank, Standard Chartered bank and Ghana Commercial Bank with the aim of comparing service quality across these three banks and determining the most important factors contributing to service quality, Hinson, Mohammed, and Mensah (2006) found that all the banks selected differ on the service quality dimensions. Their study also revealed that locally owned banks are more oriented to providing social services than the multinational banks and that, customers' expectations on all the service attributes used in their study were not met by the selected banks.

Generally, banks in Ghana have limited empirical information on the key quality dimensions that influence customers' perception and overall service quality. Each of the banks has identified itself with at least one of the dimensions of service quality they perceive to be key drivers of customers' attitude towards the excellence of the quality of service the banks provide. The service providers' perspective of what is service quality might be quite different from what customers perceive as service quality. For effective competitive decisions, it is important to understand the customers' definition and perception of service quality. Service quality has various antecedence and customers of different background characteristics may place different level of importance on each antecedent of service quality and overall perceived service quality.

Besides the problem of depth, most studies on banks' service quality focused on how quality affects customers' satisfaction with few studies measuring service quality and even when service quality was considered, the authors only compared the phenomenon among banks. There is limited empirical evidence on the dimensionality of the service quality of one particular bank in Ghana not to even talk about analyzing the dimension that greatly influences overall service quality in the industry. Therefore, this research is conducted to examine the dimensions used by customers to judge banking service quality in Ghana and to also determine which dimension greatly influences the overall service quality using Cal Bank Ghana limited as a case study.

\subsection{Research Framework}

In conceptualizing overall service quality in the banking industry in the light of the literature reviewed in prior sections, it is considered that, the following five dimensions; reliability, responsiveness, assurance, empathy and tangibility influence customer expectation and perception. Figure 2 shows the hypothesized relationships between the dimensions of service quality and overall perceived service quality. 


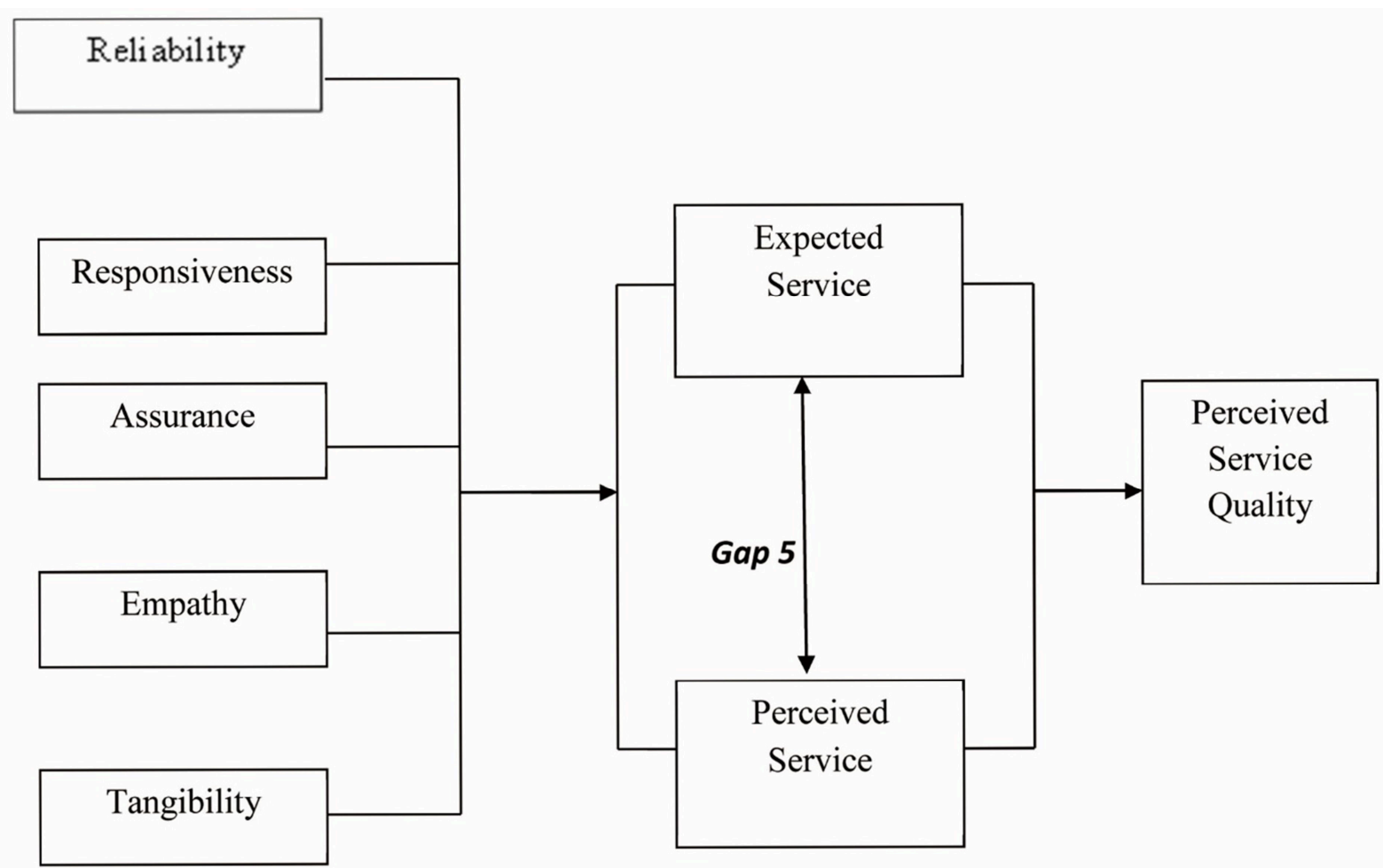

Figure 2. The research framework adopted from Fitzmmons and Fitzmmons (2011)

Note. GAP 5 is the difference between perceived or experienced service and expected service.

\section{Research Methodology}

This section presents the methodology adopted for this research including: the research design, research instrument, population and sampling.

\subsection{Research Design}

The data used in this study were mainly primary in nature. Structured questionnaire adopted from the SERVQUAL instrument was the main tool used to gather the primary data. The target population of the study is the entire customers of Cal Bank Ghana Limited in Kumasi. Hair et al. (2006) state that surveying from the entire population could be expensive and require adequate time for data collection and analysis. Consequently, convenience sampling was used to select 200 respondents across all branches of the Bank in Kumasi for this research.

\subsection{The Research Instrument}

One of the most widely used service quality instruments, SERVQUAL, developed by Parasuraman et al. $(1985,1988)$ was utilized in this study. This instrument has emerged as perhaps the most widely recognized scale in the service quality literature and has been applied to a broad range of service industries including retail banking (Parasuraman et al., 1988; 1994; Lam 1995; Newman 2001). SERVQUAL is based on perception between the difference in perceived service quality and expected service quality, and is used in explaining 
consumer perception of service quality. Users of the SERVQUAL questionnaire rate questions on a Likert scale ( $1=$ strongly disagree to $7=$ strongly agree). The SERVQUAL instrument comprises 22 statements used to assess service quality across the five dimensions already explained in this study. The questionnaires were adopted from the SERVQUAL instrument by Parasuraman et al. (1988) and Service-Quality-Audit questionnaire based on the Gap model by Parasuraman et al. (1985) and Zeithaml et al. (2009).

The questionnaire had three sections: Section A sought to gather data on the demography of the customers; section B was devoted to 22 statements grouped under five dimensions of service quality to gather data on customer expectations while section $\mathrm{C}$ used the 22 statements also grouped under five dimension to gather data on customers' perception of Cal Bank's services. Sections B and C of the questionnaire used a seven point Likert scale ranging from 'Strongly Disagree (1) through to Strongly Agree (7) from which respondents were to score the 22 statements under each section.

\section{Data Analysis and Discussion}

The analysis and interpretations of the results of this study are presented here. The content includes background of the respondents which is also analysed as the customer segment of the bank; customers' perception of service quality and the dimension that customers perceive to be most important and greatly influences overall service quality in the bank.

\subsection{Customers Demographic Data Analysis}

The demographical data of the customers were taken according to gender, age occupation as well as monthly income. The demographic data were taken to assess the customer segment of the bank and the analysis of the data is presented below.

Table 1. Customers' demography

\begin{tabular}{ccccc}
\hline Variables & Type & Frequency & Percentage & Cumulative Percent \\
\hline Age & Below 30 & 12 & 6.00 & 6.00 \\
& $31-40$ & 46 & 23.00 & 29.00 \\
& $41-50$ & 117 & 58.50 & 87.50 \\
& $51-60$ & 20 & 10.00 & 97.50 \\
Gender & Above 60 & 5 & 2.50 & 100.00 \\
& Total & 200 & 100.00 & \\
& Male & 80 & 40.00 & 40.00 \\
Occupation & Female & 120 & 60.00 & 100.00 \\
& Total & 200 & 100 & \\
& Trader & 76 & 38.00 & 38.00 \\
& Civil Servant & 62 & 31.00 & 90.00 \\
& Artisan & 43 & 21.50 & 100.00 \\
& Student & 19 & 9.50 & 47.00 \\
& Total & 200 & 100.00 & 82.50 \\
& Below GHC 500 & 94 & 47.00 & 100.00 \\
& GHC 500 - 1000 & 71 & 35.50 & \\
& Above GHC 1000 & 35 & 17.50 & \\
& Total & 200 & 100.00 & \\
\hline
\end{tabular}


From Table 1 above, more females $120(60.0 \%)$ than males $80(40.0 \%)$ participated in the survey. This could also mean that the customer base of Cal bank is dominated by females. The study also revealed that most of the respondents were within the age brackets of 31-40 and 41-50 years. This could mean that most of the customers of the bank are within the age bracket of 41-50 years. Majority of the respondents were Traders representing 76 (38.0\%). This analysis could mean that most of the customers of Cal bank are Traders. The study further revealed that most of the customers of the bank earn more than $\mathrm{GH} \phi 1,000$ as their monthly income. The demographic background indicates that most customers are grown-ups and earn more than $\mathrm{GH} \varnothing 1,000$ who may not settle for any mean service from bankers and as such constitute the right respondents in assessing service quality which is primarily judgmental.

\subsection{Expectation, Perception and Gap}

The average expectations and average perceptions of the respondents were matched to compute the overall service quality in the bank. The overall service quality score is computed as a gap between average perception score and average expectation score derived from the 22 scale items. Table 2 shows the result from analysis of the data on computation of the overall service quality.

Table 2. Service quality GAP (matching expectations against perception)

\begin{tabular}{|c|c|c|c|c|c|}
\hline \multirow[t]{2}{*}{ VARIABLE } & \multicolumn{2}{|c|}{ EXPECTATION } & \multicolumn{2}{|c|}{ PERCEPTION } & \multirow{2}{*}{$\begin{array}{l}\text { GAP } \\
\text { Mean Difference }\end{array}$} \\
\hline & Mean & St. Dev. & Mean & St. Dev. & \\
\hline \multicolumn{6}{|l|}{ RELIABILTY } \\
\hline $\begin{array}{l}\text { Cal Bank provide their services at the } \\
\text { time they promise to do so }\end{array}$ & 6.36 & 0.80 & 5.01 & 0.78 & -1.35 \\
\hline $\begin{array}{l}\text { When I have a problem, staff show a } \\
\text { sincere interest in solving it }\end{array}$ & 6.23 & 0.81 & 4.58 & 0.95 & -1.65 \\
\hline $\begin{array}{l}\text { Cal Bank perform their services right } \\
\text { the first time }\end{array}$ & 6.09 & 1.03 & 4.24 & 1.23 & -1.85 \\
\hline $\begin{array}{l}\text { Cal Bank provide their services as } \\
\text { promised }\end{array}$ & 6.49 & 0.83 & 4.76 & 1.18 & -1.73 \\
\hline $\begin{array}{l}\text { Cal Bank keep error-free records on } \\
\text { customers }\end{array}$ & 6.72 & 1.06 & 5.11 & 1.08 & -1.62 \\
\hline \multicolumn{6}{|l|}{ RESPONSIVENESS } \\
\hline $\begin{array}{l}\text { Cal Bank tell me exactly when services } \\
\text { will be performed }\end{array}$ & 5.89 & 1.03 & 4.56 & 0.99 & -1.34 \\
\hline Cal Bank give prompt service & 6.00 & 1.04 & 4.71 & 0.93 & -1.30 \\
\hline $\begin{array}{l}\text { Cal Bank is always willing and happy } \\
\text { to help me }\end{array}$ & 6.21 & 0.85 & 4.37 & 1.20 & -1.85 \\
\hline $\begin{array}{l}\text { Staff are never too busy to respond to } \\
\text { my request }\end{array}$ & 6.23 & 0.78 & 4.44 & 1.29 & -1.79 \\
\hline \multicolumn{6}{|l|}{ ASSURANCE } \\
\hline $\begin{array}{l}\text { The services of employers make me } \\
\text { feel confident about Cal Bank }\end{array}$ & 5.22 & 1.23 & 6.51 & 0.87 & 1.29 \\
\hline $\begin{array}{l}\text { I feel safe doing transactions at Cal } \\
\text { Bank }\end{array}$ & 4.89 & 1.50 & 6.30 & 0.85 & 1.41 \\
\hline $\begin{array}{l}\text { Cal Bank staff are consistently } \\
\text { courteous with me }\end{array}$ & 4.51 & 1.75 & 6.38 & 1.12 & 1.87 \\
\hline $\begin{array}{l}\text { Staff have knowledge about Cal Bank } \\
\text { to answer my questions }\end{array}$ & 5.35 & 1.32 & 6.56 & 0.88 & 1.22 \\
\hline
\end{tabular}




\section{Il Macrothink}

\begin{tabular}{|c|c|c|c|c|c|}
\hline EMPATHY & & & & & \\
\hline $\begin{array}{l}\text { Customers are dealt with on individual } \\
\text { basis }\end{array}$ & 5.05 & 1.48 & 6.21 & 0.98 & 1.16 \\
\hline $\begin{array}{l}\text { Cal Bank have convenient operating } \\
\text { hours }\end{array}$ & 5.20 & 1.37 & 6.45 & 0.96 & 1.25 \\
\hline Staff gives me personal attention & 4.82 & 1.50 & 6.20 & 1.15 & 1.38 \\
\hline Cal Bank have my best interest at heart & 4.45 & 1.74 & 6.31 & 0.98 & 1.87 \\
\hline $\begin{array}{l}\text { Staff understand my specific needs } \\
\text { TANGIBLES }\end{array}$ & 4.72 & 1.69 & 6.43 & 1.13 & 1.72 \\
\hline $\begin{array}{l}\text { Cal Bank has modern equipment in } \\
\text { banking hall and offices }\end{array}$ & 6.23 & 0.88 & 4.58 & 1.33 & -1.65 \\
\hline $\begin{array}{l}\text { Cal Bank physical facilities are visually } \\
\text { appealing }\end{array}$ & 6.40 & 0.81 & 4.63 & 1.22 & -1.77 \\
\hline $\begin{array}{l}\text { Staff appearance is neat and } \\
\text { professional }\end{array}$ & 6.07 & 0.95 & 4.46 & 1.40 & -1.61 \\
\hline $\begin{array}{l}\text { Cal Bank has visually appealing signs, } \\
\text { symbols, advertisement board, } \\
\text { pamphlets and other artifacts. }\end{array}$ & 6.13 & 0.84 & 4.37 & 1.58 & -1.76 \\
\hline Average Reliability Score & 6.38 & 0.24 & 4.74 & 0.35 & -1.64 \\
\hline Average Responsiveness Score & 6.08 & 0.16 & 4.52 & 0.15 & -1.50 \\
\hline Average Assurance Score & 4.99 & 0.37 & 6.44 & 0.13 & 1.45 \\
\hline Average Empathy Score & 4.85 & 0.29 & 6.32 & 0.12 & 1.47 \\
\hline Average Tangibility Score & 6.20 & 0.14 & 4.51 & 0.14 & -1.69 \\
\hline Overall service quality Score & 5.69 & 0.71 & 5.32 & 0.91 & -0.37 \\
\hline
\end{tabular}

Table 2 summarizes standard deviations and mean/averages of customers' expectations and perceptions of Cal Bank's service quality. The table shows that the average Expectation of the respondents was 5.69 whereas Perception was 5.32.

This means that that there is a service quality gap of -0.37 . This indicates that the customer's perception of the bank's service quality falls short of their expectations. Again, it could be seen from Table 2 that three of the five dimensions recorded negative service quality gap and two recorded positive service quality gap. However, no meaningful conclusions could be made until it is established whether the gaps are significantly different from zero. A one sample test was therefore carried out to see whether the gaps are significantly different from zero. Table 3 shows the results of the significance test.

Table 3. One sample test of the gap scores of the dimensions and overall service quality

\begin{tabular}{llllll} 
& & \multicolumn{5}{l}{ Test Value = } \\
\cline { 5 - 6 } & $\begin{array}{l}\text { Mean } \\
\text { Gap }\end{array}$ & $\begin{array}{l}\text { Sta. } \\
\text { Dev. }\end{array}$ & $\mathrm{t}$ & df & Sig. (2-tailed) \\
\hline Reliability & -1.64 & 1.318 & -8.189 & 199 & .000 \\
Responsiveness & -1.50 & 1.211 & -6.413 & 199 & .000 \\
Assurance & 1.45 & 1.701 & 4.628 & 199 & .061 \\
Empathy & 1.47 & 1.421 & 7.521 & 199 & .065 \\
Tangibility & -1.69 & 1.312 & -10.215 & 199 & .000 \\
Overall Service Quality & -.37 & 1.506 & -9.118 & 199 & .000 \\
\hline
\end{tabular}




\section{MlMacrothink}

Table 3 shows that negative gaps were all significant whiles the positive gaps were all insignificant at 0.05 significant level. This indicates that the perceptions of the respondents for Reliability, Responsiveness and Tangibility fall short of the respondents' expectations for those three dimensions of service quality. On the other hand, Assurance and Empathy have insignificant positive dimensions which show that there is no significant difference between customers' expectations and perceptions of those dimensions. This could mean that Assurance and Empathy are the dimensions customers perceive to be up to expectation in $\mathrm{Cal}$ bank Limited. In other words, Cal bank is particular about showing courtesy and instilling confidence in customers to make customers feel safe transacting with them as well as showing interest in customers' specific need and giving them individual attention. Table 3 also shows that the overall service quality gap score is -0.37 . Therefore, it may be concluded that the overall service quality gap score of -0.37 shows that the overall service quality of the banks is below expectations. This is also confirmed by the test results $[\mathrm{t}=-9.118(\mathrm{P}=0.00)]$ which indicates that the -0.37 is significant at the significance level of 0.05 .

\subsection{Regression Results}

One of the objectives of this study was to identify the key dimension that significantly drives customers' judgment of overall service quality at Cal Bank Limited. Data was therefore analysed to identify the dimension which has the most influence on overall service quality in the bank. A regression analysis technique was used to regress the gap scores of overall service quality on the perceived service quality scores of the five dimensions identified in the study. Table 4 shows the result of the regression analyses.

Table 4. Regression analysis of dimensions of service quality and overall service quality

\begin{tabular}{llllll}
\hline Model & $\mathbf{B}$ & $\begin{array}{l}\text { Stan. } \\
\text { Error }\end{array}$ & Beta & $\mathbf{t}$ & Sig \\
\hline 1 (Constant) & -5.687 & .131 & - & -37.878 & .000 \\
Reliability & .513 & .025 & .501 & 9.118 & .000 \\
Responsiveness & .260 & .028 & .249 & 8.519 & .000 \\
Assurance & .051 & .022 & .056 & 2.454 & .010 \\
Empathy & .082 & .027 & .064 & 2.912 & .002 \\
Tangibility & .129 & .029 & .104 & 4.152 & .000 \\
\hline $\mathrm{R}$ & $\mathrm{R}$ Square & Adjusted R Square & \multicolumn{2}{l}{ Durbin Watson } \\
$.843^{\mathrm{a}}$ & .718 & .717 & & \multicolumn{2}{l}{1.891} \\
\hline
\end{tabular}

Dependent Variable: Service Quality.

From Table 3, the regression results show that all the independent variables are significant. Again, from Table 4, it could be observed that all the dimensions of service quality identified are significant predictors of overall service quality at the level of 0.05 . The R square of 0.718 shows that the five dimensions are able to explain $71.8 \%$ of the value of overall service quality scores. All the "B" values and "Beta" values are positive indicating a direct 
relationship between the dimensions and overall service quality. However, the most influential dimension and key driver of the overall service quality scores in this context is reliability with the highest coefficient $[\mathrm{B}=0.513,(\mathrm{P}=0.000)]$. The results also imply that for every 1 unit change in service quality, Cal Banks must improve upon reliability by 0.513 holding all other variables constant; for every 1 unit change in service quality, Cal Bank must improve upon responsiveness by 0.26 holding all the other variables constant and for every 1 unit change in service quality, Cal Bank must improve upon Tangibility by 0.129 .

\section{Conclusion}

This study was conducted to examine service quality at Cal bank limited and to identify the key factor that significantly drives overall service quality in the bank. The study identified that overall customers' perception with the dimensions investigated into were lower than customers' expectation as indicated by a negative SERVQUAL score (-0.37). From the results obtained, the first dimension (reliability) showed a difference of -1.64 , Responsiveness showed a difference of -1.50 , tangibility showed a difference of -1.69 . Empathy and Assurance recorded positive service quality gaps of 1.47 and 1.5 respectively. Finally, the study found that all the five dimensions of service quality significantly influence the service quality of the bank and that the bank implements all the five service quality dimensions (reliability, empathy, assurance, tangibility and responsiveness) which is to say that the bank strives to be at its best when it comes to quality. The results show that customers are dissatisfied with the overall level of service quality provided by Cal bank. However, customers are satisfied with empathy and assurance dimensions. Findings from the gap analysis revealed that the key dimension that greatly influences overall service quality in the bank is reliability, which has the highest coefficient. This means that Cal bank needs to pay a greater attention to the reliability components makeup of the bank and improve upon the reliable services provided to customers whilst maintaining the other dimensions if not to make it better. Therefore, this study recommends that Cal Bank pays more attention to reliability issues such as providing excellent service to their customers, resolving complaints promptly, and delivering to customers as to when and how they need their services. Further studies on service quality in banks could also be engineered in other banks and/or with greater geographical setting in Ghana or even banks in different countries for comparison based on the data in this study.

\section{References}

Albrecht, T. (2003). The importance of assessing customer perception. Retrieved from http://aqsiteam.com/custperception.htm

Amoako, G. K. (2012). Improving Customer Service in the Banking Industry-Case of Ghana. International Business Research, 5, 134. https://doi.org/10.5539/ibr.v5n4p134

Bonsu \& Mensah. (2013). An assessment of service Quality in three banks operating in Ghana. Journal of Business Research, 1(1\&2), 7-20. https://doi.org/10.5539/ijms.v5n2p81

Domingo, R. (2003). Business Management Articles, banking service management. Retrieved from http://www.rtdonline.com/BMA/BSM/7.html 
Fitzsimmons, J. A., \& Fitzsimmons, M. J. (2011). Service Management: Operations, Strategy and Information Technology (6th ed.). Singapore: McGraw-Hill Inc.

Ghobadian, A., Speller, S., \& Jones, M. (1994). Service Quality Concepts and Models. International Journal of Quality \& Reliability Management. https://doi.org/10.1108/02656719410074297

Gronroos, C. (1984). A service quality model and its marketing implications. European Journal of Marketing; 18(4), 36-44. https://doi.org/10.1108/EUM0000000004784

Hartline, M. D., \& Jones, K. C. (1996). Employee Performance Cues in a Hotel Service Environment: Influence on Perceived Service Quality, Value, and Word-of-Mouth Intentions. Journal of Business Research, 35(3), 207-215. https://doi.org/10.1016/0148-2963(95)00126-3

Hinson, R., Mohammed, A., \& Mensah, R. (2006). Determinants of Ghanaian bank service quality in a universal banking dispensation. Banks and Bank Systems, 1(2).

Jamal, A., \& Naser, K. (2002). Customer satisfaction and retail banking: an assessment of some of the key antecedents of customer satisfaction in retail banking. International Journal of Bank Marketing, 20(4), 146-160. https://doi.org/10.1108/02652320210432936

Kheng, L. L., Mahamad, O., Ramayah, T. M., \& Rahim, M. R. (2010). The impact of service quality on customer loyalty: a study of banks in Penang, Malaysia. International Journal of Marketing Studies, 2(2), 57. https://doi.org/10.5539/ijms.v2n2p57

Levesque, T., \& McDougall, G. (1996). Determinants of customer satisfaction in retail banking. International Journal of Bank Marketing, 14(7), 12-20. https://doi.org/10.1108/02652329610151340

Lovelock, C. H., \& Wirtz, J. (2007). Service marketing: people, technology, Strategy (6th ed.). New Jersey: Prentice Hall.

Nukpezah, D., \& Nyumuyoa, C. (2009). What drives customer loyalty and profitability. analysis of perspectives from retail customers in Ghana's banking industry (Master's Thesis). School of Management, Blekinge Institute of Technology.

Ojasalo, J. (2001). Managing customer expectations in professional services. Managing Service Quality, 11. https://doi.org/10.1108/09604520110391379

Parasuraman, A. (1998). Customer service in business-to-business markets: an agenda for research. Journal of Business and Industrial Marketing, 13. https://doi.org/10.1108/08858629810226636

Parasuraman, A., Zeithaml, V. A., \& Berry, L. L. (1985). A conceptual model of service quality and its implications for future research. Journal of Marketing, 49(4), 41-50. https://doi.org/10.1177/002224298504900403

Parasuraman, A., Zeithaml, V. A., \& Berry, L. L. (1988). SERVQUAL: A multiple-item scale for measuring consumer perceptions of service quality. Journal of Retailing. 
Rahaman, M. M., Abdullah, M., \& Rahman, D. A. (2011, July). Measuring Service Quality using SERVQUAL Model: A Study on PCBs (Private Commercial Banks) in Bangladesh. Business Management Dynamics, pp. 1-11.

Sackey, A. R., Adebayo, S., Oppong, M. A., Mensah, A. E., \& Annor, L. (2012). The Effect of Quality Service on Customer Satisfaction, Loyalty and Retention in the Ghanaian Banking Industry (A case of Barclays Bank Ghana Limited- BBGL). European Journal of Business and Management, 7(3), 1-89.

Saghier, E. N., \& Demyana, N. (2013). Service Quality Dimensions and Customers' Satisfactions of Banks in Egypt. Proceedings of 20th International Business Research Conference. Dubai, UAE.

Williams, A. R. T., van der Wiele, A. \& Dale, B. G. (1999). Quality costing: a management review. International Journal of Management Reviews, 1(4), 441. https://doi.org/10.1111/1468-2370.00022

Zeithaml, V. A., \& Bitner, M. J. (1996). Services Marketing, international edition, McGraw Hill, New York.

Zeithaml, V. A., Bitner, M. O., \& Gremler, D. E. (2009) Services Marketing: Integrating Customer Focus Across the Firm. Mcgraw-Hill/Irwin, New York.

\section{Copyrights}

Copyright for this article is retained by the author(s), with first publication rights granted to the journal.

This is an open-access article distributed under the terms and conditions of the Creative Commons Attribution license (http://creativecommons.org/licenses/by/4.0/). 